DOl: 10.19195/2353-8546.8.18

\author{
TOMASZ NAKONECZNY* \\ Uniwersytet im. Adama Mickiewicza (Poznań, Polska) \\ ORCID: 0000-0002-4241-7862
}

\title{
Rosyjski literaturocentryzm w kontekście postkolonialnym
}

\begin{abstract}
Russian literaturocentrism in the context of postcolonial studies. The development of postcolonial studies as a research discipline to a large extent depends on their representatives' ability to overcome their own post-colonial conditions. This particularly applies to researchers representing imperial cultures. Russian post-colonial studies develop their own cognitive categories in relation to the issue of Russian and Soviet imperialism, while avoiding many potential inspirations contained in the book by Ewa Thompson "Imperial Knowledge: Russian Literature and Colonialism", which became an important reference for postcolonial research in Poland and Ukraine. The author of the article outlines the shaping of Russian literaturocentrism, and then, tries to answer the question of whether and to what extent it can be a useful issue for research on the imperial determinants of Russian culture.
\end{abstract}

Keywords: postcolonial studies, Russian literature, Ewa Thompson, internal colonization, external colonization

Pogląd, że to właśnie literatura zajęła w dziewiętnasto- i dwudziestowiecznej kulturze rosyjskiej najbardziej wyróżnione miejsce i że również dla świata zewnętrznego stała się tejże kultury swoistym znakiem rozpoznawczym, należy już dzisiaj, przynajmniej w środowisku rosjoznawczym, do rzędu obiegowych. Określenie „rosyjski literaturocentryzm” nie wydaje się ani bardziej ekscentryczne, ani zarazem mniej sugestywne niż pozostałe rosyjskie konstanty kulturowe. Oznacza usytuowanie literatury w roli depozytariuszki wyjątkowych wartości, narodowych i ogólnoludzkich,

* Adres do korespondencji: Instytut Wschodni UAM, ul. Umultowska 89D, 61-614 Poznań. E-mail: tomnak@amu.edu.pl. 
a także - co najmniej do czasu pojawienia się telewizji — w roli najbardziej dostępnej w rosyjskich warunkach sieci dystrybucji kapitału symbolicznego. W przypadku literatów oznacza natomiast wyniesienie do rangi porównywalnej pod niejednym względem z tą, jaka przysługiwała niegdyś kapłanom - pisarz/poeta charakteryzowany jest w nowoczesnej kulturze rosyjskiej nieodmiennie w wysokich rejestrach. Puszkin pisze o sobie: „И неподкупный голос мой был эхо русского народа”, Jewgienij Jewtuszenko zaś w słynnym wierszu Поэт в России - больще, чем поэт ${ }^{2}$ nazywa poetę obrazem swojego wieku (образ века своего). Literaturocentryzm rosyjski, biorąc pod uwagę jego historyczne znaczenie, jego społeczną doniosłość, a także ukryty w nim wymiar tożsamościowy, należałoby wpisać do kanonu pojęć wyznaczających pole semantyczne rosyjskości.

Trzeba jednak zauważyć, że sam termin „literaturocentryzm” wraz z jego derywatami („literaturocentryczny”, „literaturocentrycznośc” itp.) robi w Rosji karierę dopiero u schyłku lat osiemdziesiątych i w latach dziewięćdziesiątych XX wieku. W radzieckich opracowaniach dotyczących literatury wydaje się on nieuchwytny; brakuje go na przykład w monumentalnej Encyklopedii literackiej (Литературная энциклопедия, 1929-1939). Choć rzecz wymagałaby jeszcze gruntownej analizy źródłowej, wydaje się, że mamy tu do czynienia ze zjawiskiem niejako „wyprzedzającym” w czasie dyskursywny metajęzyk, w którym jest ono artykułowane dzisiaj. Co jednak charakterystyczne, coraz większej frekwencji pojęcia w tekstach poświęconych kondycji współczesnej literatury rosyjskiej towarzyszy rosnące przeświadczenie o faktycznym zaniku w Rosji tradycyjnie rozumianego literaturocentryzmu ${ }^{3}$.

Niemało uwagi poświęcono przyczynom zaistnienia literaturocentrycznego fenomenu. Wielu badaczy dostrzega jego zakorzenienie w kulturze staroruskiej, która szczególną czcią otaczała święte księgi. Anna Woźniak podkreśla rolę ruskiego piśmiennictwa średniowiecznego „jako zjawiska kształtującego i cementującego [...] średniowieczną kulturę wczesnoruską" ". Michaił Berg z kolei dostrzega wagę momentu przejścia do świeckości, w ramach której utrwalono „stereotyp sakralnego stosunku do słowa”, a pisarza (świeckiego następcy kapłana) ,jako władcy myśli”; na późniejszym etapie ważną rolę w umacnianiu pozycji literatury miałaby również

1 А. Пушкин, Эхо русского народа, https://www.stihi.ru/2010/01/10/8357 (dostęp: 20.09.2018).

2 Е. Евтушенко, Поэт в России - больще, чем поэт, https://www.stihi.ru/2007/11/17/1193 (dostęp: 20.09.2018).

3 Do literaturoznawców promujących pogląd o zaniku tradycyjnego rosyjskiego literaturocentryzmu zaliczany jest Andriej Nemzer. Badacz ten przy różnych okazjach zwraca uwagę na wielorakie uwarunkowania tego procesu, zarówno kulturowe, jak i socjologiczne czy psychologiczne: „Мы не хотели верить в собственные силы, в собственное творческое начало, в собственную большую традицию [...]. Отсюда легкость, с которой мы не просто усвоили слухи о конце литературоцентризма, но и перетолковали их в императив отрицания литературы как таковой” - idem, „Замечательное десятилетие. О русской прозе 90-х годов”, Новый Мир 1, 2000, http://magazines. russ.ru/novyi_mi/2000/1/nemzer.html (dostęp: 25.09.2018).

${ }^{4}$ A. Woźniak, „O literaturze rosyjskiej, jej nauczaniu i literaturocentryzmie”, Roczniki Humanistyczne 64, 2016, z. 7, s. 43. 
odegrać charakterystyczna dla Rosji opozycja inteligencji i ludu ${ }^{5}$. Inteligencja, podobnie jak literatura, wzięła na siebie zadania, których w warunkach rosyjskich nie mogły się podjąć ani instytucje społeczne (szkoły wyższe, prasa, partie polityczne), ani dyskursy pozaliterackie (nauka, myśl społeczna, publicystyka polityczna itp.) ${ }^{6}$. Oczywiście w przypadku literatury realizacja tych zadań nie byłaby możliwa, gdyby miała się odbywać w ramach obiegu pozaoficjalnego; pewna przychylność ze strony państwa, wyrażająca się między innymi względną łagodnością cenzury, była w tej mierze niezbędna. Zdaniem Richarda Pipesa przychylność ta wynikała z faktu, że działalność literacka nie była postrzegana przez carat jako godząca w jego interesy ${ }^{7}$. Pogląd ten wydaje się jednak uproszczeniem. Wiemy przecież, jak niepewna i niejednoznaczna była pozycja przedstawicieli środowiska literackiego w okresie jego kształtowania się, zwłaszcza za panowania Katarzyny II i Mikołaja I. Symbolicznym poświadczeniem niestabilności pisarskiego losu mogą być choćby losy Mikołaja Nowikowa czy skazanego na śmierć Aleksandra Radiszczewa, zdaniem Katarzyny II „buntownika groźniejszego niż Pugaczow”.

W rzeczywistości relacje patrymonialnej z ducha władzy i coraz bardziej zróżnicowanego, a przy tym świadomego swojej wartości świata literackiego dalekie były od schematyczności. Podręcznikowy schemat jest w tym przypadku prosty — po jednej stronie opresyjny, pozbawiony subtelności i zrozumienia dla intelektualnych dystynkcji aparat biurokratyczny, po drugiej natomiast niechętne mu, postępowe, połączone węzłem moralnej solidarności, środowisko literackie. Establishmentowi carskiemu wcale nie musiało zależeć na literaturze jako takiej, jednak nie mógł pozostawać głuchy na jej rosnący przez cały XIX wiek prestiż, który w przypadku autorów i tekstów w taki czy inny sposób opozycyjnych mógł wiązać się z niepokojąco dużą siłą społecznego oddziaływania. Z kolei środowiska twórcze trudno uznać za ideowo-moralny monolit. W istocie nie dystansowały się one gremialnie ani jednoznacznie od wartości fundujących rosyjskie samodzierżawie. Casus Dostojewskiego, pisarza miary światowej, eksplorującego głębie ludzkiej natury, a jednocześnie pozostającego w horyzoncie wartości rosyjskiego nacjonalizmu, moglibyśmy traktować jako kolejną ilustrację mitu o niedocieczonej idiosynkratyczności artysty jako

5 М. Берг, „О статусе литературы”, Дружба Народов 7, 2000, http://magazines.russ.ru/druzhba/2000/7/berg.html (dostęp: 23.09.2018).

6 „Literatura XIX-wieczna, główna trybuna wyrażania się rosyjskiej świadomości społecznej jako wypowiedź napełniona treściami filozoficznymi i publicystycznymi, przejęła de facto funkcje katedr uniwersyteckich, a także czasopism, które nie mogły pełnić swoich właściwych ról z powodu pogłębiającego się stale w ciągu wieków ucisku cenzury, presji oraz represji ze strony czynników oficjalnej władzy" - A. Woźniak, op. cit., s. 55.

7 „W połowie XVIII wieku literatura stała się pierwszą dziedziną twórczości, którą władze tolerowały. [...] W litej niegdyś bryle systemu patrymonialnego pojawiła się szczelina; literatura stała się pierwszą dziedziną działalności ludzi służebnych, która nie miała nic wspólnego z interesami władcy. Nigdy już nie straciła tej wyjątkowej pozycji. Od tej pory i do dziś dnia jest prywatnym królestwem, podległym innym władcom i innym prawom" - R. Pipes, Rosja carów, przeł. W. Jeżewski, Warszawa 2006, s. 260. 
takiego, gdyby nie fakt, iż ten akurat przypadek jest dla kultury rosyjskiej z wielu względów symptomatyczny.

Obie strony, przy wszystkich dzielących je różnicach, zachowywały względem siebie wystarczająco dużo wyrozumiałości, a niekiedy nawet rewerencji i „przywiązania", byśmy mogli mówić o braku fundamentalnej dychotomii światopoglądowej wewnątrz świata rosyjskich elit. Narrator Tołstojowskiej Anny Kareniny, dzieła mogącego uchodzić pod niejednym względem za krytyczne wobec panujących w Rosji porządków, reprezentuje pod wieloma innymi względami punkt widzenia zbliżony do światopoglądu ówczesnego rosyjskiego establishmentu. Każda próba przypisania tej powieści do aksjologii obozu „postępowego” bądź „zachowawczego” natrafia na trudności niezależne od jej artystycznego formatu.

Pęknięcie, w dodatku szybko się pogłębiające, zarysuje się gdzie indziej — w relacji elit i ludu, co stanowi dziś dla rosyjskiego dyskursu postkolonialnego kanwę opowieści o rosyjskiej kolonizacji wewnętrznej. Gwoli ścisłości należy dodać, że rychło uczestnikiem podziału stanie się też radykalny ruch rewolucyjny, nominalnie stojący po stronie ludu, jednak faktycznie reprezentujący odrębne interesy i własną aksjologię.

Wydaje się, że przyczyn względnej jednolitości światopoglądowej władzy i środowisk literackich należałoby szukać wśród trudniej uchwytnych i głębiej z rosyjską tradycją związanych przesłanek kulturowych. Na jedną z nich zwraca uwagę Jerzy Faryno, gdy pisze o realizowaniu przez literaturę rosyjską ideału duchowości/uduchowienia (духовность, душевность), współokreślającego - razem z innymi wyznacznikami rosyjskiego charakteru narodowego, takimi jak pokora czy cierpliwość - zarówno rosyjskie samopostrzeganie („duchowość, uduchowienie zachowała i może zaoferować światu tylko kultura rosyjska”), jak i rosyjską percepcję Zachodu, modelowanego w tym przypadku jako negatywne odniesienie ( $\mathrm{w}$ świetle rosyjskiej duchowości/uduchowienia „kultura zachodnia jawi się jako »nieuduchowiona «, »racjonalna«, »materialna « oraz »chłodna«, »konwencjonalna« »egoistyczna« brak jej »serdeczności $=$ ciepła «") ${ }^{8}$. Nietrudno zgodzić się z Michaiłem Bergiem, gdy pisze on o charakterystycznej dla kultury rosyjskiej „magicznej aureoli” słowa, która wynosi twórczość literacką ponad inne, niewerbalne formy sztuki, a także stanowi czynnik odróżniający rosyjskie figuracje pisarza/poety od zachodnich (potrzeba takich odróżnień jawi się jako istotny współczynnik kształtowania rosyjskiego autoobrazu) ${ }^{9}$.

8 Zob. J. Faryno, „Духовный/Душевный”, [w:] Stownik mentalności rosyjskiej, red. A. de Lazari, Katowice 1995, s. 27-28.

9 „В Западной Европе поэт находился в одном ряду с другими деятелями искусств (Вольтер называл писателей »жалким племенем, пишущим для пропитания«, »подонками человечества«, »литературным отребьем «, а Руссо определял поэтическое творчество как »самое подлое из ремесел«). В русской культуре слово (или право на поэтическую манифестацию) было окружено магическим ореолом, роль властителя дум изначально принадлежала только представителям социальной элиты, в то время как живописец, музыкант, актер - профессии, попадающие в ряд между поваром и парикмахером, »низкие« занятия, приличествующие крепостному, вольноотпущеннику или иностранцу, да и само слово »художник« в языке XVIII века применяется

Miscellanea Posttotalitariana Wratislaviensia 8, 2020

(C) for this edition by CNS 
Trzeba równocześnie przyznać, że rosyjski dyskurs (meta)literacki wykazał się podziwu godną skutecznością w narzucaniu światu swoich autodefiniujących kategorii: uduchowienie, dobroć (доброта) czy współczucie (сострадание) weszły już chyba na stałe do grona pojęć identyfikujących literaturę rosyjską w świecie.

Przewrót bolszewicki nie spowodował zaniku etosu literaturocentrycznego $\mathrm{w}$ Rosji. Przeciwnie, w okresie radzieckim mamy nawet do czynienia z jego swoistym, mimowolnym umacnianiem — pośrednio, niemniej w sposób widoczny — poprzez rozwój masowego rynku wydawniczego, a także instytucjonalizację różnych form działalności literackiej, podnoszącą zarówno prestiż zawodu pisarza, jak i społeczną rangę kontaktu $\mathrm{z}$ literaturą. Ale i szerzej $-\mathrm{z}$ kulturą artystyczną jako taką. Wysoki status nadaje się literaturze już w uchwale Biura Politycznego z roku 1925 pod tytułem „O polityce partii w dziedzinie literatury”, w której mówi się o niej jako o części wielkiej rewolucji kulturalnej ${ }^{10}$. Wydaje się co prawda, że w oczach pragmatycznych elit sowieckich nie literatura jako taka, lecz książka, materialny nośnik upowszechniania określonych, rewolucyjnych treści, miała być podstawowym narzędziem oddziaływania na wyobraźnię mas, na jakim owym elitom zależało w pierwszej kolejności. Nie zmienia to, rzecz jasna, realnego znaczenia przeobrażeń rynku wydawniczego oraz związanej z nim polityki państwa, o jakich mowa. $\mathrm{Na}$ trudną do przecenienia $\mathrm{z}$ punktu widzenia recepcji literatury rolę książki w okresie radzieckim zwraca uwagę Jewgienij Dobrienko w pracy Формовка советского читателя. Социальные и эстетические предпосылки рецепции советской лиmepamypul ${ }^{11}$.

W praktyce nastawienie do książek i literatów było w ZSRR, zwłaszcza w pierwszych latach nowych rządów, zróżnicowane, w znacznym stopniu uzależnione od oceny ich ideowej wiarygodności. Kategorią organizującą liczne ważne dyskusje i spory, jakie wywiązywały się wokół zagadnienia ideowości, byli tak zwani poputczycy, którym to mianem określano ludzi postrzeganych jako faktyczni bądź potencjalni sprzymierzeńcy bolszewików, „niepełnowartościowych” ideowo - zdaniem tychże - ze względu na niedostateczne rozpoznanie wyzwań czasu. Stanowiska, jakie zajmowali wobec nich przedstawiciele elity rewolucyjnej, były nader różne: od nacechowanego nieufnością krytycyzmu środowiska RAPP-u do przychylnego i pragmatycznego uznania niezbędności sojuszu z nimi wyrażanego przez ludowego komisa-

только к ремесленнику, то есть к человеку, работающему руками. Человеку благородного происхождения быть художником стыдно" - М. Берг, op. cit.

10 Постановление Политбюро ЦК РКП(б) О политике партии в области художественной литературы (18.06.1925 г.), http://www.hist.msu.ru/ER/Etext/USSR/1925.htm (dostęp: 23.09.2018).

11 „Целая серия директив и постановлений, начиная с 1918 года закрепляет новый социальный статус книги: »Книга должна явиться могущественнейшим средством воспитания, мобилизации и организации масс вокруг задач хозяйственного и культурного строительства«, - гласило постановление ЦК ВКП(б) от 15 августа 1931 года »Об издательской работе " Е. Добренко, Формовка советского читателя. Социальные и эстетические предпосылки рецепuии советской литературы, Санкт-Петербург 1997, s. 152. 
rza oświaty Anatolija Łunaczarskiego ${ }^{12}$. „Kwestia poputczykowska” odwołuje nas do poważnego dylematu, jaki wyłonił się przed ówczesnymi organizatorami życia ideologicznego i który jawi się jako istotny w kontekście rozważań nad ewolucją rosyjskiego literaturocentryzmu: czy w odniesieniu do oceny zjawisk artystycznych, zwłaszcza literackich, powinny brać górę kryteria ideologiczne czy też inne, pozaideologiczne (estetyczne, etyczne, intertekstualne, społeczne itp.)? To kwestia, która powróci w kontekście badań postkolonialnych.

Wspomniany dylemat znalazł odzwierciedlenie w toczącym się w drugiej połowie lat trzydziestych sporze między progresistami a woprekistami, zakończonym ostatecznie, jak wiemy, zwycięstwem tych pierwszych. Triumf ideologii komunistycznej nad wartościami fundującymi tradycyjny model kultury artystycznej można interpretować - i tak się na ogół czyni - w kategoriach politycznych jako kolejny etap centralizacji tego obszaru życia społecznego. Można jednak patrzeć nań, tak jak to czyni Michaił Epsztejn, jako na etap długofalowej ewolucji kultury, której wyróżnionymi ogniwami są modernizm i postmodernizm.

Мне представляется - pisze Epsztejn - что сходство постмодернизма и коммунизма как программных методов воздействия на общественное сознание далеко не случайно, они представляют собой в России две фазы становления одного идейно-эстетического проекта. Если коммунизм провозглашал грядущее торжество идей, преображающих реальность, то постмодернизм обнаруживает уже отсутствие какой-либо другой реальности, кроме реальности самих идей (знаков, образов, наименований) ${ }^{13}$.

Epsztejn wymienia wiele elementów zbliżających intelektualnie oba projekty (komunistyczny i postmodernistyczny), na przykład podejrzliwość w stosunku do oświeceniowej proweniencji konceptu integralnej podmiotowości czy afirmowanie nieuświadamianych przez podmiot mechanizmów kształtowania rzeczywistości (na przykład wynikających ze struktury relacji klasowych czy z uwikłania w sieć zależności językowych) ${ }^{14}$, jednak dla nas najważniejsza jest możliwość dostrzeżenia w tym zestawieniu pewnej radykalizacji czynnika semiotycznego — zarówno praktyki socrealistyczne firmowane przez komunizm, jak i (inter)tekstualizacja świata, będąca identyfikatorem postmodernistycznych poetyk, prowadzą w efekcie do daleko idącej literaturyzacji rzeczywistości ${ }^{15}$. Ma ona jednak niewiele wspólnego $\mathrm{z}$ tradycyjnym

12 C. Madajczyk, Klerk czy intelektualista zaangażowany?, Poznań 1999, s. 145.

13 М. Эпштейн, Постмодерн в России. Литература и теория, Москва 2000, s. 54-55. „Сама быстрая и легкая смена коммунистического проекта постмодерным заставляет подозревать в них некоторую общность. Это подтверждается, с одной стороны, пристрастием российских практиков постмодернизма, писателей и художников, к соц-арту, к коммунистической образности и набору соцреалистических идейных клише” - ibidem, s. 55.

14 М. Эпштейн, Постмодерн в русской литературе, Москва 2005, s. 73-74.

15 „Соцреализм потому так важен для понимания социалистической реальности, что вся она представляет собой соцреализм, то есть такую высокую, »литературную« степень знаковости, когда не остается самих означаемых, но означающие замыкаются в своем кругу, отсылают друг к другу. Советская идеология так настаивала на реализме, потому что притязала на пол-

Miscellanea Posttotalitariana Wratislaviensia 8, 2020

(C) for this edition by CNS 
rosyjskim literaturocentryzmem, ufundowanym na logocentrycznej wizji poety/pisarza-kapłana, depozytariusza wyższych prawd, sumienia narodu. Wizji, w której — by posłużyć się semiotyczną dychotomią pojęciową - to, co znaczące, odróżnia się wyraźnie od tego, co znaczone. Podporządkowanie literatury ideologii socrealistycznej, sprawiające, że ta pierwsza ze strażniczki wartości pojmowanych jako realne i trwałe (prawda, dobroć, duchowość) przeobraziła się w promotorkę wartości kreowanych na realne i trwałe (socrealistyczna symulakrowość, o której pisał Epsztejn), było dla samej literatury działaniem w istocie głęboko deprecjonującym. Obnażyło konstruktywistyczny wymiar działalności literackiej jako takiej, zmniejszając w ten sposób radykalnie jej kapitał symboliczny i otwierając przed nią dwie potencjalne drogi rozwojowe. Odtąd literatura mogła być domeną intertekstualności lub rozrywki; praktyka postmodernistyczna pokazała jednak, że możliwości te wcale się nie wykluczały.

Nie zmienia to faktu, że formalnie właśnie literaturze przypisywano w okresie stalinowskim najważniejsze zadania ideowo-artystyczne związane z budową nowego ustroju. Proklamowanie realnego socjalizmu jako obowiązującej metody twórczej na Zjeździe Pisarzy Radzieckich (1934), dopiero później rozszerzone na pozostałe rodzaje działalności artystycznej, było mimowolnym ukłonem w stronę wielkiej tradycji literackiej XIX i początku XX wieku.

Instrumentalizacja literatury i jej specyficznego etosu nie mogła nie stać się, jeśli nie od razu, to z czasem, czynnikiem rozkładu w stosunku do rosyjskiego literaturocentryzmu. Podobnie jak undergroundowy konceptualizm, który w latach siedemdziesiątych i osiemdziesiątych obnażał pustkę partyjno-państwowej nowomowy, również polityka faktycznej, wbrew podniosłym deklaracjom, utylitaryzacji literatury, do jakiej doszło w latach trzydziestych i czterdziestych, przyczyniła się do daleko idących przewartościowań w obrębie rosyjskiego dyskursu (meta)literackiego. Dyskurs ów dość szybko zaczął, jak już wspomniałem, wykazywać świadomość zaniku paradygmatu literaturocentrycznego bądź też jego znaczącej transformacji (Berg, Czuprynin, Nemzer), próbując przy tym dać tego odpowiednią diagnozę, a także przedstawić własną wizję dalszego ciągu kulturowej ewolucji ${ }^{16}$.

Stanowiska tego rodzaju znajdowały odzwierciedlenie w postawach samych twórców. Postacią uosabiającą bodaj najwymowniej tę nową, wyraźnie już antyliteraturocentryczną orientację, okazał się kojarzony z postmodernizmem Wiktor Pielewin, którego najbardziej znaczące wystąpienia — zarówno te stricte literackie, jak i te wyrażające się w planie medialnej autokreacji - przypadły na dwie pierwsze dekady po rozpadzie ZSRR.

Ten właśnie okres wypada uznać za przełomowy w dziedzinie ewolucji instytucji pisarskiej w Rosji oraz rosyjskiego modelu literatury — następująca w nim ku-

ную семиотизацию всей реальности, ее превращение в текст" - М. Эпштейн, Постмодерн в Pоссии..., s. 58.

16 Por. М. Берг, Литературократия. Проблема присвоения и перераспределения власти в титературе, Москва 2000. 
mulacja tendencji postmodernizujących (utajonych, lecz wyraźnie zaznaczających się w kulturze, zwłaszcza samizdatowej, od lat siedemdziesiątych) oraz spóźnionych efektów „niedokończonej” modernizacji (wczesna awangarda) spowodowała otwartą tematyzację konfliktu na linii rosyjskie konstanty kulturowe-nowoczesny/ ponowoczesny konstruktywizm. Konflikt ten można wprawdzie dekodować w terminach poetyk poststrukturalistycznych, jednak z dzisiejszej perspektywy czasowej ważniejsze jest to, że towarzyszące mu zmiany w zakresie języka deskrypcji wcale nie musiały przekładać się na zmiany w sferze - ugruntowanych na przestrzeni kilku epok - wyobrażeń i nawyków mentalnych. Postmodernizacja literatury rosyjskiej, a także dyskursów pokrewnych, zwłaszcza takich jak literaturoznawstwo czy refleksja metakulturowa, z jednej strony wiązała się z rozbiórką niektórych tradycyjnych rosyjskich autoobrazów (co było zresztą jej znakiem rozpoznawczym dla skupionych na spektakularnych przejawach rosyjskich praktyk literackich obserwatorów spoza rosyjskiego świata), z drugiej jednak te same autoobrazy traktowała jako platformę porozumienia $\mathrm{z}$ kształtowanym dopiero przez nową estetykę i nową filozofię odbiorcą. Rozbiórka nie była przeto gruntowna. Niekiedy zresztą zmiany, o jakich mowa, zdawały się polegać na imitacji zachodnich wzorów; sprowadzały się, można powiedzieć, do bycia tych wzorców swoistą, lokalną stylizacją.

Pielewin, postmodernista eksploatujący konsekwentnie i z sukcesem tradycyjne rosyjskie residua kulturowe (podejrzewany nawet przez Siergieja Korniewa o bycie ukrytym rosyjskim klasykiem-ideologiem ${ }^{17}$ ), może jawić się jako modelowy przypadek literata budującego własną pozycję zawodową - jako nowoczesnego pisarza i ironicznego intelektualisty - w polu symbolicznym wytyczonym przez literaturocentryczną klasykę rosyjską. Budowanie polega tu, jak wiele na to wskazuje, na świadomej autokreacji, opierającej się na prestiżu literackiego powołania i jednocześnie zorientowanej na manifestacyjną negację tradycyjnych przesłanek tego prestiżu. W rezultacie owego dialektycznego współdziałania kapitału przeszłości i atrakcyjnej dla współczesnego odbiorcy ironiczności literatura - w wydaniu Pielewinowskim — znów wykazuje się zdolnością do skupiania na sobie uwagi, niesienia ważnych przesłań i eksplorowania istotnych społecznie tematów. Autor Generation „P”, powieści cierpko i prześmiewczo rozprawiającej się z rosyjskim literaturocentryzmem, mimowolnie streszcza $\mathrm{w}$ jednym $\mathrm{z}$ wywiadów, na czym polega owocna rynkowo synteza (auto)ironicznego indywidualizmu i literaturocentrycznej z ducha służby słowu:

Писатель - это человек, который отвечает перед текстом, который он пишет, а не перед читателями или критиками. Поэтому это очень одинокое занятие. Кроме того, я никого никуда не веду, а просто пишу для других те книги, которые развлекли бы меня самого. Собственно, они меня и развлекают, потому что я их первый читатель. Я далек от того, чтобы относиться к себе серьезно ${ }^{18}$.

17 Por. С. Корнев, „Столкновение пустот: может ли постмодернизм быть русским и классическим?", Новое литературное обозрение 28, 1997.

18 Вдали от комплексных идей живешь, как Рэмбо - day by day, Liza Nowikowa w wywiadzie z Wiktorem Pielewinem, http://pelevin.nov.ru/interview/o-komrs/1.html (dostęp: 20.09.2018).

Miscellanea Posttotalitariana Wratislaviensia 8, 2020

(C) for this edition by CNS 
Duży autorytet społeczny wiąże się zwykle z poważnymi zobowiązaniami natury moralnej. Nie inaczej jest w wypadku literatury. W krajach o wyróżnionej społecznie pozycji literatury i literatów, takich jak Rosja czy Polska, zobowiązania te dotyczą różnych wymiarów życia społecznego, co dodatkowo zwiększa ich znaczenie ${ }^{19}$. Pozaliterackie zadania tudzież oczekiwania, jakimi obarczano pisarza/poetę rosyjskiego bądź polskiego, wynikają wprawdzie z określonych deficytów w zakresie szeroko rozumianej reprezentatywności obywatelskiej i światopoglądowej, co z kolei odzwierciedla charakterystyczne dla tych krajów — przy wszystkich dzielących je różnicach - struktur społecznych (na przykład brak wyemancypowanej klasy mieszczańskiej), jednak etyczną moc i zasięg oddziaływania obie literatury zawdzięczają czemuś więcej - zdolności do tworzenia pewnych ogólnych ram percepcyjnych, integrujących najbardziej reprezentatywne składniki wspólnotowego światopoglądu.

Tradycyjnemu autorytetowi literatury rzucane są od czasu do czasu wyzwania. Obecnie w awangardzie krytycznie usposobionych wobec niego dyskursów znalazły się przede wszystkim te spod znaku poststrukturalizmu i kulturalizmu (postmodernistyczny, feministyczny itp.). Osobną listę zarzutów formułują studia postkolonialne, łączące kompetencje poststrukturalistyczne z kulturalistyczną wrażliwością etyczną, dla których literatura i przyległe do niej formy wypowiedzi (publicystyka, krytyka literacka itp.) stanowią w pierwszej kolejności przestrzeń wyrażania i zarazem maskowania relacji dominacji i przemocy. Literatura jawi się jako wyjątkowo atrakcyjny poznawczo obszar takich relacji ze względu na swoją semiotyczną wielopłaszczyznowość i praktycznie nieograniczony zakres odniesień intertekstualnych odzwierciedlają się w niej zjawiska subtelniejsze i zależności bardziej wielorakie niż w innych, mniej zróżnicowanych dyskursach. Warto pamiętać, że cele, jakie stawiają przed sobą postkolonialiści, wykraczają wyraźnie poza domenę badawczą; nie tylko próbują oni identyfikować, analizować i charakteryzować wspomniane zależności, ale też dążą do ich przezwyciężenia. Na początku i na końcu każdego przedsięwzięcia spod znaku postcolonial studies jako jego inicjalne oraz finalne ogniwo znajduje się postulat moralny. Nie zawsze wyrażony wprost, ale kluczowy z punktu widzenia całości przedsięwzięcia - określa on jego sens, potwierdza złożoność postkolonialnego projektu, motywowanego z jednej strony względami społecznymi, a z drugiej postrukturalistyczną teorią dyskursu.

Wydawałoby się, że dekonstrukcja rosyjskiego literaturocentryzmu, którą rozpoczął socrealizm, a „dokończy”" postmodernizm, nie zostawia już wiele miejsca kolejnemu projektowi dekonstrukcyjnemu. Studia postkolonialne mogą jednak wzbogacić refleksję nad fenomenem literaturocentryzmu, posługując się własnymi kategoriami poznawczymi i własnym aparatem analitycznym. By wykazać, na czym miałoby owo wzbogacenie polegać, należałoby najpierw zapytać, co właściwie przemawia za umieszczeniem rosyjskiego literaturocentryzmu wśród pojęć wyznaczających semantyczne pole badań postkolonialnych, takich jak imperializm, subwersja,

19 Ibidem. 
peryferyjność czy orientalizm. Zanim spróbujemy odpowiedzieć na to pytanie, rozważmy sprawę ogólniejszej wagi: w jaki sposób dyskurs postkolonialny legitymizuje swoje zainteresowanie Rosją?

Zacznijmy od konstatacji tyleż oczywistej, co zaskakującej: literatura rosyjska nie należy w badaniach postkolonialnych do obszarów eksplorowanych $\mathrm{z}$ intensywnością i systematycznością, których można by się spodziewać po sukcesie Trubadurów imperium Ewy Thompson ${ }^{20}$. Przyjęło się uważać, że to klasyczne już dziś studium nad rolą, jaką w kształtowaniu się rosyjskiego imperializmu odegrała szeroko rozumiana kultura humanistyczna, zwłaszcza literatura piękna, jest punktem zwrotnym w postrzeganiu Rosji oraz jej relacji ze światem zewnętrznym. Warto jednak zastanowić się nad naturą owej przełomowości. Nie mamy tu bowiem do czynienia $z$ inkluzją nowych faktów, lecz z reinterpretacją faktów i zjawisk znanych, i to niekiedy w dużej skali (między innymi rosyjski model władzy, rosyjska polityka, zarówno wewnętrzna, jak i międzynarodowa, oraz rosyjska klasyka literacka). Jednocześnie reinterpretacja ta nie dokonuje się w ramach językowo-konceptualnej ani ideowej autonomii - nie tylko zapożyczona jest gruntownie z terminologii postcolonial studies, projektu stworzonego do badań nad światem pozarosyjskim (Zachód i jego kolonie), ale też, zmierzając świadomie ku demistyfikacji swojego obiektu (Rosja jako zamaskowany kolonizator), ujawnia pewien rys ideologicznej interesowności/ stronniczości.

Oczywiście perspektywizm badawczy jako taki nie może być przedmiotem zarzutu, wszak stanowi on - parafrazując kantowską metaforę - kulturową formę naoczności. Pionierska próba zmierzenia się z zagadnieniem rosyjskiego imperializmu podjęta przez $\mathrm{E}$. Thompson uświadamia liczne trudności związane $\mathrm{z}$ aplikowaniem słownika postkolonialnego do nowych obszarów dyskursywnych. Zauważony rys stronniczości to efekt usytuowania w określonej wspólnocie doświadczeń, warunkującej obraz innych wspólnot i przesądzającej między innymi to, na jakim poziomie metaforyczności będzie odbywała się komunikacja z nimi. Z punktu widzenia studiów postkolonialnych szczególnie użytecznego zbioru danych dotyczących interakcji kulturowych dostarcza sposób modelowania Innego/Obcego. Jak duże rozpiętości występują między wspomnianymi poziomami, mogą zaświadczyć obrazy inności, z jakimi mamy do czynienia w ramach tak zwanej świadomości potocznej: od konwencjonalnego, „opisowego” kategoryzowania (na przykład „Islandczycy to wyspiarze i jak na wyspiarzy przystało...”) do figuratywności odwołującej się do jawnie trybalistycznych stereotypów („Nie będzie Niemiec pluł nam w twarz”).

W przypadku samej autorki Trubadurów, Polki urodzonej w 1937 roku na Kresach (w Grodnie), wykształconej w PRL-u, od lat siedemdziesiątych przedstawicielki amerykańskiego świata akademickiego, zabiegającej o podniesienie statusu Europy Środkowo-Wschodniej w badaniach slawistycznych, doświadczenie wspólnotowe,

20 E. Thompson, Trubadurzy imperium. Literatura rosyjska i kolonializm, przeł. A. Sierszulska, Kraków 2000. 
o jakim mowa, może jawić się — szczególnie w kontekście postkolonialnego wyczulenia na znaczenie centro-peryferyjnych konfrontacji - jako ze wszech miar wyjątkowe. W ogólniejszym wymiarze jest to kanoniczny przypadek intelektualistki pochodzącej z kraju peryferyjnego, której twórczość pozwala się dekodować w kategoriach misji realizowanej na terenie metropolii (amerykańskie, a szerzej zachodnie, elity humanistyczne). Misji polegającej między innymi na zaznajamianiu metropolii z racjami swojej źródłowej, peryferyjnej wspólnoty, przy których użyciu wspólnota ta usiłuje wytłumaczyć - urbi et orbi - swoje położenie w świecie.

Właśnie to, że dyskurs postkolonialny możemy postrzegać jako przestrzeń artykulacji określonych wspólnotowych idiosynkrazji, ich uwarunkowań wewnętrznych i odniesień zewnętrznych, uświadamia, jak istotną rolę odgrywa w nim fakt zakorzenienia danego badacza $w$ regionalnych strukturach mentalnych i w regionalnym doświadczeniu historycznym. Samo jednak przypisanie do określonej „grupy interesów" na kulturowej mapie świata nie powinno być przyczyną poważniejszych zastrzeżeń. Prawdziwy problem polega tutaj na czym innym - na występowaniu strukturalnych (instytucjonalnych) barier, które wspomnianą artykulację utrudniają, a niekiedy i uniemożliwiają. Trudność w przełamywaniu spetryfikowanych układów władzy i zależności, zarówno w skali globalnej (Pierwszy-Trzeci Świat), jak i regionalnej (Europa Wschodnia), wynika tutaj nie z niedostatku argumentacji moralnej czy z funkcjonalnej niesprawności aparatu dyskursywnego, lecz z obiektywnych, instytucjonalnych słabości.

Forma dyskursywna zwana Rosją — zauważa polsko-amerykańska badaczka — jest rzeczywistością intelektualną, której przemiana będzie, z natury rzeczy, powolna. Nagromadzenie anglojęzycznych odczytań literatury rosyjskiej, które zamykają oczy na problem rosyjskiego kolonializmu oraz agresywnego nacjonalizmu nie zniknie z dnia na dzień, jako że nie działają w tym kierunku żadne nieodparte interesy polityczne bądź kulturowe ${ }^{21}$.

Podjęta przez Thompson próba rozpoznania struktur mentalnych, które są fundamentem obrazu Rosji jako „niewinnego" imperium, uruchamia co najmniej dwa ważne wymiary eksplanacyjne: podmiotowy i prakseologiczny. Refleksja nad pierwszym z nich, przywołanym przed chwilą, dotyczy w istocie pewnej sytuacji komunikacyjnej, dlatego dobrym punktem wyjścia mogłoby być opisanie tej ostatniej w kategoriach schematu Jakobsona. Myślę o opisaniu raczej w trybie pewnego eksperymentu myślowego niż wiernej aplikacji, ponieważ schemat Jakobsona zasadniczo nie nadaje się do analizowania złożonych zjawisk kulturowych (wykazuje zresztą również ograniczenia na poziomie „mikro”, o czym świadczą korekcje i uzupełnie-

${ }^{21}$ Ibidem, s. 3. Por. „Teoria zawsze ustala normy funkcjonowania praktyki. Gdy praktykujesz, by tak rzec, tworzysz teorię, w nieunikniony sposób powodując, że to praktyka nałoży normy na teorię, zamiast stać się zwykłym przykładem jej niedokładnej aplikacji” - G.C. Spivak, Strategie postkolonialne, przeł. A. Górny, M. Kropiwnicki, Warszawa 2011, s. 61. 
nia, jakim podlega ${ }^{22}$ ). Ma jednak przynajmniej jedną niezaprzeczalną zaletę — jest prosty i dzięki temu pozwala lepiej sobie uzmysłowić występowanie, a także znaczenie poszczególnych elementów aktu komunikacji (nadawca, odbiorca, kontekst itp.) oraz zachodzące między nimi zależności (funkcje komunikatu), które w innym razie mogłyby ujść uwagi lub zostać niedocenione. Przyjęło się zresztą uważać, że w prostocie modelu jakobsonowskiego wyraża się jego użyteczność. W odniesieniu do wieloaspektowych, skomplikowanych aktów komunikacji, z jakimi mamy do czynienia $\mathrm{w}$ relacjach centro-peryferyjnych, może tak być wyłącznie na mocy paradoksu — prostota modelu dezawuuje niejednoznaczność odpowiadającego jej stanu rzeczy.

Jako przedmiot „eksperymentu” weźmiemy, rzecz jasna, książkę Thompson. Trudności wyłaniają się już na etapie ustalenia, kto jest w niej nadawcą, a kto odbiorcą. Zaznaczmy, że chodzi tu o relacje kulturowe, intertekstualne; idiosynkratyczność jednostkową zmuszeni jesteśmy w rozważaniach kulturalistycznych traktować jako sferę interpretansa (przesłanek interpretacyjnych, zgodnie $\mathrm{z}$ terminologią Jerzego Kmity dotyczącą interpretacji humanistycznej; interpretandum byłyby w danym przypadku właśnie wspomniane „relacje kulturowe”). Z jaką sytuacją komunikacyjną mamy tu w ogóle do czynienia? Czy tworzą ją, zgodnie z naszym intuicyjnym przeświadczeniem, takie podmioty, jak amerykański establishment akademicki, środkowo-wschodnioeuropejskie oraz rosyjskie elity intelektualne? Kogo zatem $\mathrm{w}$ wyznaczanej przez tę sytuację interakcji reprezentują Trubadurzy? Slawistykę amerykańską, dyskursy tożsamościowe narodów Europy Środkowo-Wschodniej? A może po prostu dyskurs postkolonialny jako taki, którego kontekst przedmiotowy ulega tutaj poszerzeniu o Rosję i jej sąsiadów? Możliwość, która nastręcza się jako najprostsza, a mianowicie, że Ewa Thompson reprezentuje tutaj samą siebie, zmuszeni jesteśmy uznać za zbyt prostoduszną w świetle faktu, że zajmuje ona w sposób widoczny określone stanowisko badawcze. Idiosynkratyczność jednostkową podporządkowaliśmy już zresztą wcześniej egzemplaryczności socjokulturowej (badacz jako uczestnik pewnej sytuacji postkolonialnej).

Możemy więc zadać daleko bardziej kłopotliwe pytanie: czy w zarysowanej tu konsytuacji realizuje się faktyczna komunikacja, czy też raczej mówimy o możliwościach jedynie teoretycznych? Czy komunikat nadawcy (tak czy inaczej określonego) może być słyszalny dla potencjalnego odbiorcy (tak czy inaczej określonego)? Nie chodzi, rzecz jasna, o mnożenie trudności partykularnych, lecz o uwypuklenie jednej zasadniczej - interpelacja postkolonialna skierowana do Rosji problematyzuje w danym przypadku sam akt komunikacji międzydyskursywnej ${ }^{23}$. Jest to w istocie,

22 Por. W. Czechowski, „Zakłócenia w językowej komunikacji jako problem badawczy”, Linguistica Bidgosiana 2004, https://repozytorium.ukw.edu.pl/ (dostęp: 21.09.2018).

${ }^{23}$ Nie mniejsze trudności wyłonią się, gdy spróbujemy osadzić podmioty nakreślonej konsytuacji w pewnym układzie relacyjnym i przypisać doń jakobsonowskie funkcje. Jeśli nawet potrafimy zadowalająco wyodrębnić główną część kontekstu, na którą składają się rosyjskie praktyki imperialne w rodzimej literaturze, publicystyce i historiografii, możemy mieć w danym przypadku kłopot z oszacowaniem funkcji poznawczej, jaką schemat Jakobsona przypisuje relacji komunikat-kontekst. Czy jest 
pozostając przy terminologii jakobsonowskiej, interpelacja metajęzykowa. Dotyczy eksperymentu intelektualnego, który polega na próbie przyswojenia przez dyskurs postkolonialny (uosabiany $\mathrm{w}$ rozpatrywanej sytuacji przez jego przedstawicielkę) rosyjskich auto- i heteroobrazów. Interpelacja pociąga za sobą potrzebę ustalenia adekwatności pojęć (rosyjskie-postkolonialne), a na poziomie operacyjnym - wykazania celowości ich użycia. W danym przypadku nie chodzi jednak tylko o sporządzenie katalogu rozbieżności i dojście do porozumienia w wyniku merytorycznej nad nimi debaty. Albowiem w danym przypadku sytuacja komunikacyjna w klasycznym sensie nie istnieje, do czego za chwilę wrócę ${ }^{24}$.

Thompson zwraca uwagę na wybrane oznaki konstytuowania się w ciągu wieków Rosji jako mocarstwa imperialnego. Celem przyświecającym badaczce jest pokazanie, że proces ten przebiegał równolegle - przynajmniej od przełomu XVIII i XIX wieku — w ramach szeroko rozumianego dyskursu tożsamościowego, w szczególności w literaturze (ujmując rzecz w terminach symboliki imienniczej — od Puszkina do Sołżenicyna). Kształtujący się — nieuchwytnie dla świata zewnętrznego - rosyjski dyskurs imperialny miał zdaniem polsko-amerykańskiej badaczki wykazywać cechy podobne do tych, które ujawniały ,jawnie" imperialne dyskursy zachodnie. To właśnie uzasadniało wykorzystanie do jego eksploracji kategorii z zakresu postcolonial studies.

Nad studiami postkolonialnymi, których zasięg przedmiotowy — geograficzny, problemowy, dyscyplinarny - wciąż się powiększa, ciąży niebezpieczeństwo zbyt łatwej transgresji pojęć. Tymczasem pojęcia funkcjonalne w jednej domenie badawczej, na przykład w literaturoznawstwie, wcale nie muszą wykazywać się użytecznością w innych domenach. Na przykład kategoria resentymentu potrafi bardzo dobrze „sprawdzać się" w ramach studiów literaturoznawczych (nosicielem resentymentu jest tu na ogól jednostka: bohater lub narrator), jednak jej aplikowanie do analiz socjologicznych, rozpoznających zjawiska zbiorowe, czyni z niej własność emergentną, a więc poznawczo co najmniej kłopotliwą.

Refleksja nad zasygnalizowanymi niedogodnościami to swoiste loci communes badań postkolonialnych dotyczących Europy Wschodniej. W odniesieniu do Rosji skalę trudności powiększa okoliczność już przywołana - nie mamy tu do czynienia z pełnowymiarowym aktem komunikacji (wyodrębnieni uczestnicy, jasno określony kontekst, ustalone reguły metajęzykowe), lecz jedynie z próbą interpelacji o wieloznacznych skutkach. Zasadniczo każda poważniejsza próba przeciwstawienia się

to $\mathrm{w}$ istocie funkcja dominująca w Trubadurach, jak mielibyśmy prawo się spodziewać? Czy kulturowe imputacje, owe naturalne, jako się rzekło, „formy naoczności”, nie stają się w tym konkretnym tekście źródłem poznawczej konfuzji?

${ }^{24}$ Klasyczna dla studiów postkolonialnych sytuacja to taka, w której poddane interpelacji imperium nie tylko nie uchyla się od odpowiedzialności, ale też wykazuje zainteresowanie realnym wyjaśnieniem swojego i swoich interpelantów położenia. Mamy z nią niewątpliwie do czynienia w przypadku postimperialnej Wielkiej Brytanii. 
dominującym narracjom (meta)rosyjskim ${ }^{25}$, w szczególności próba rewizji niezwykle odpornych na takie zabiegi rosyjskich autonarracji tożsamościowych, naraża się na zarzut - nie zawsze formułowany wprost - polityczności. Ale „wina” nie leży wyłącznie po stronie rosyjskiej, jak chce wielu, czego koronnym dowodem mogą być - nieco paradoksalnie - sami Trubadurzy Thompson.

Trudno przecież uznać, by rekontekstualizacja obrazu Rosji zyskiwała tutaj istotnie nowy, paradygmatyczny wymiar, uwzględniający rosyjską specyfikę historyczno-kulturową. Trudno też mówić o zapoczątkowaniu przez Trubadurów nowego języka, odchodzącego od starych struktur metaforycznych i zastępującego je nowymi, wolnymi od semantyczno-symbolicznych obciążeń przeszłości czy - mówiąc po prostu - od nagromadzonych przez pokolenia uprzedzeń. Nieco paradoksalnie perspektywa wytyczona przez E. Thompson, jakkolwiek zapewne ożywcza dla odbiorcy zachodniego i otwarcie ukierunkowana na modernizację tradycyjnego wizerunku Rosji, czego koronnym dowodem jest posłużenie się przez autorkę postkolonialną, a w pewnej mierze również feministyczną, matrycą pojęciową, w istocie sprzyja konserwowaniu wielu potocznych, negatywnych wyobrażeń tudzież klisz poznawczych, prefigurujących Rosję jako swoiste enfant terrible cywilizowanego świata ${ }^{26}$.

Zagadnienie rosyjskiej kolonizacji nie jest na rosyjskim gruncie badawczym zupełnie nowe. Wcześniej podejmowali je jednak głównie historycy ${ }^{27}$. Rosyjska „odpowiedź” na postkolonialną interpelację ${ }^{28}$ obejmuje już szersze spektrum dyskursywne i - co dla niej charakterystyczne - koncentruje się na tych aspektach imperialnej przeszłości, które komplikują (a w istocie - uniejednoznaczniają) jej obraz. Jednym z takich aspektów jest zjawisko określane jako „wewnętrzna kolonizacja” (внутренняя колонизация). Pojęcie to zostało już w rosyjskiej literaturze postkolonialnej głęboko zinternalizowane i traktowane jest w niej jako opisowe, choć polskiemu odbiorcy mogłoby wydawać się nieco bałamutne ${ }^{29}$. Za jego promotora może

${ }^{25}$ Chodzi nie tylko o narracje wewnętrzne, rosyjskie, ale również zewnętrzne, sprzyjające utrwalaniu rosyjskich autostereotypów.

${ }^{26}$ Wydaje się, na co zresztą niejednokrotnie zwracano już uwagę, że „winna” temu stanowi rzeczy jest, przynajmniej częściowo, sama Rosja, która za sprawą swoich realnobytowych uwarunkowań (lądowe, w przeciwieństwie do zachodnioeuropejskich potęg imperialnych, usytuowanie względem terytoriów podporządkowanych), a także własnej specyfiki tożsamościowej (kraj o zróżnicowanym rodowodzie kulturowo-politycznym) nie poddaje się łatwo taksonomiom dyskursów zewnętrznych, zwłaszcza postkolonialnego, jako tego, dla którego głównym odniesieniem pozostają interakcje Pierwszego i Trzeciego. Oczywiście można taki pogląd zdezawuować (czyni to zresztą sama E. Thompson) jako kolejną zasłonę dymną, mającą przykryć rosyjską zaborczość pozorami rzekomych komplikacji.

27 Warto w tym kontekście zwrócić uwagę na opublikowane niedawno prace Matwieja Lubawskiego, powstałe jeszcze w okresie międzywojennym; por. idem, Обзор истории Русской колонизаиии с древнейших времен и до ХХ века, Москва 1996.

${ }^{28}$ W tym przypadku używam określenia „postkolonialna interpelacja” w szerszym, światowym kontekście, nie zaś w odniesieniu do książki E. Thompson. Sam rozwój badań postkolonialnych występuje tu w roli sui generis interpelanta.

29 „В отличие от классических империй с заморскими колониями в разных концах света, колонизация России имела центростремительный характер. Известия о русских шаманах, бы-

Miscellanea Posttotalitariana Wratislaviensia 8, 2020

(C) for this edition by CNS 
dziś uchodzić Aleksander Etkind, współczesny rosyjski kulturoznawca działający na emigracji, którego praca pod tytułem Internal colonisation. Russia's imperial experience $^{30}$ została dostrzeżona również $\mathrm{w}$ środowisku polskich postkolonialistów ${ }^{31}$. Natura kolonizacji wewnętrznej jawi się w optyce rosyjskich autorów jako złożona. Oznacza bowiem istnienie kilku równoległych układów zależnościowych, takich jak inteligencja-lud, aparat władzy państwowej-społeczeństwo, a także imperium-jego kolonie „wewnętrzne”: kaukaskie bądź środkowoazjatyckie. Posługiwanie się kategorią „wewnętrzności” w odniesieniu do nie-rosyjskich ziem i narodów imperium może sprawiać wrażenie aroganckiego potwierdzania własnej wyższości. Powinniśmy jednak widzieć w nim raczej nieodparty nawyk postrzegania wewnątrzimperialnych stosunków jako „domowych”. Większą jednak konfuzję wywołują rosyjskie wykładnie „kolonizacji zewnętrznej” (внешняя колонизация), drugiego, obok „kolonizacji wewnętrznej”, filaru pojęciowego w tamtejszej debacie postkolonialnej. Wbrew odruchowemu skojarzeniu, jakie może towarzyszyć polskiemu odbiorcy, wektor „zewnętrzności” jest tutaj najczęściej skierowany do wewnątrz: „kolonizacja zewnętrzna" to kolonizacja Rosji przez siły zewnętrzne (Zachód, chrześcijaństwo, podmioty odpowiedzialne za procesy globalizacyjne) ${ }^{32}$.

Co charakterystyczne, te i podobne zabiegi transformujące podstawowe znaczenie terminu „kolonizacja” w rozumieniu studiów postkolonialnych wiodą do rozmywania wymiaru etycznego. W świecie, w którym imperium okazuje się przedmiotem kolonizacji, a jego działalność kolonizacyjna polega przeważnie na podporządkowywaniu sobie własnych („wewnętrznych”) obszarów, bezcelowe okazuje się mówienie o winie i odpowiedzialności. Ów rys wieloznaczności prowadzącej do zwekslowania odpowiedzialności za imperialną/kolonialną przemoc na tajemnicze, nieuchwytne moce globalizacji (nowoczesności) widoczny jest niekiedy w myśleniu Madiny Tłostanowej, najbardziej bodaj widocznej w przestrzeni tekstualnej rosyjskiej postkolonialistki. Stwierdza ona, że

линах, мощах, общинах, сектах и, наконец, народниках не уступали сенсациям из экзотических заморских колоний. В российских столицах эти известия воспринимались так же, как в европейских, с одной лишь разницей: этот экзотический народ был своим, он говорил на нашем языке и был источником нашего благополучия. Россия колонизовала саму себя, осваивала собственный народ. То была внутренняя колонизация, самоколонизация, вторичная колонизация собственной территории" - А. Эткинд, Фуко и тезис внутренней колонизации: постколониальный взгляд на советское прошлое, http://magazines.russ.ru/nlo/2001/49/etkind-pr.html (dostęp: 25.09.2018).

30 Por. A. Etkind, Internal colonisation. Russia's imperial experience, Cambridge 2011.

31 Por. B. Bakuła, „Rosyjska wewnętrzna kolonizacja”, Porównania 15, 2014, s. 341-356.

32 „Ведь Россия на протяжении нескольких столетий осваивала два взаимопротивоположных направления колонизации - внешней и внутренней. Она завоевывала колонии и при этом сама была колонией. Она была Востоком для Европы и Америки (да и то не всегда), но Западом для республик Средней Азии и Кавказа. Она была страной, повелевавшей странами и континентами, но сами повелители были рабами имперской идеологии, или просто рабами" - М. Берг, Постколониальный дискурс и проблема успеха в современной русской литературе, http://mberg.net/pstk/ (dostęp: 17.09.2018).

Miscellanea Posttotalitariana Wratislaviensia 8, 2020

(C) for this edition by CNS 
my wszyscy — i trzeci świat, i dawny świat socjalistyczny, i nawet Zachód/Północ - w różnym stopniu skażeni jesteśmy formami globalnej kolonialności jako nieodłącznej cechy nowoczesności. Konsekwencją jest bezkrytyczne przyjęcie istniejącej w tym świecie hierarchii, gdzie wszyscy mają wyznaczone miejsce, i ludzie, nawet ci, którzy są z tego miejsca zadowoleni (jak w przypadku wielu europejskich krajów postsocjalistycznych, które stały się państwami serwilistycznymi, obsługującymi „prawdziwych” Europejczyków), są na śmierć przerażeni na myśl, że ich pozycja w tej hierarchii może zostać obniżona ${ }^{33}$.

Co ciekawe, mamy tu równocześnie do czynienia z mimowolną dyskredytacją krajów Europy Środkowo-Wschodniej jako serwilistów obsługujących zachodnich Europejczyków. Te i podobne (vide koncept subaltern empire Wiaczesława Morozowa) ${ }^{34}$ ujęcia Rosji jako (post)imperium uwikłanego w niefortunne dla siebie zależności ${ }^{35}$ świadczą o dwóch istotnych z punktu widzenia niniejszych rozważań kwestiach: 1. interpelacja postkolonialna zgłoszona przez E. Thompson w Trubadurach imperium nie spotkała się z adekwatną merytorycznie i pojęciowo odpowiedzią po stronie rosyjskiej; 2 . charakterystyczne dla rosyjskiego dyskursu postkolonialnego jest swoiste, nie zawsze uchwytne wprost, uwieloznacznianie i rozmywanie definiowanych przez światowe postcolonial studies relacji zależności na linii centrum-peryferie.

Wizja rosyjskiego kolonializmu/imperializmu, jaką proponują Trubadurzy imperium, opiera się - nie akcentując tego — na rosyjskim literaturocentryzmie. To właśnie klasycznej literaturze rosyjskiej XIX i XX wieku przypisana została w książce E. Thompson wyjątkowo doniosła rola w dziele kreacji imperialnego etosu oraz - co nie mniej ważne - w dziele maskowania tudzież uzasadniania imperialnych praktyk. Można oczywiście polemizować z takim stanowiskiem, zwracając uwagę na to, że autorka koncentruje się na wybranych przykładach (co prawda sugestywnych) poświadczających występowanie takich praktyk i że w związku z tym trudno roz-

33 M. Tłostanowa, „Postsowieckość $\neq$ poskolonialność $\neq$ postimperialność, czyli co robić po końcu historii?", przeł. P. Fast, ER(R)GO. Teoria-Literatura-Kultura 2015, nr 2 (31), s. 147.

34 V. Morozov, Russia's postcolonial identity. A subaltern empire in a Eurocentric world, Basingstoke 2015.

35 „The permanent error of the Russian/Soviet empire was its inconsequence. On the one hand, it strove to build its own separate variant of globality/modernity - an Orthodox kingdom and later, a Soviet world. On the other hand, the concrete strategies of building the Russian/Soviet modernity had to be attuned to the Western one and here Russia chose a doomed way of catching up with Europe and proving that it out-wested the West. This wish has alternated periodically with the rejection of everything European and the retreat into the jingoism that we witness today. The Russian imperial discourses demonstrate a Janus-faced nature of this empire which always felt itself a colony in the presence of the West and at the same time half-heartedly played the part of the caricature - civilizer in its non-European, mostly Islamic colonies. The Soviet empire in its subaltern imperial nature was not essentially different from the Czarist one, though it reformulated the main developmentalist slogan in a more radical way, attempting to build a socialist modernity - to catch up and leave behind, while also escalating its global geopolitical appetites. As for the relation to the colonies, the Soviet tactic did not change much - it became even more cruel and refined, based on methodical elimination of all alternative thinking and being" - M. Tlostanova, Towards a decolonization of thinking and knowledge: a few reflections from the world of imperial difference, https://antville.org/static/sites/m1/files/madina_tlostanova_decolonia_thinking.pdf (dostęp: 17.09.2018). 
patrywać przywołane przez nią zjawisko imperializmu w literaturze w kategoriach reprezentatywności. Rosyjska koncentracja na fenomenie kolonizacji wewnętrznej, jakkolwiek na pierwszy rzut oka mogąca sprawiać wrażenie próby odciągnięcia uwagi świata od własnych imperialnych win, wymagałaby jednak wnikliwszego i sprawiedliwszego potraktowania. W szczególności konfrontacji z analogicznym zjawiskiem $\mathrm{w}$ innych kulturach o imperialnej charakterystyce, na przykład w polskiej kulturze sarmackiej, modelującej obraz rzeczywistości narodowej zgodnie ze szlacheckocentryczną aksjologią.

Klasyczne (w sensie postkolonialnym) formy figuracji Innego/Obcego rzadko chyba występują w literaturze rosyjskiej w postaci uzasadniającej stawianie ich w centrum uwagi badaczy postkolonialnych. Choć rzecz wymagałaby osobnego studium, daleko bardziej wyrazista opozycja swojskości i obcości zarysowuje się tutaj na płaszczyźnie relacji społecznych (klasowych). Dlatego - mimo wszystkich zastrzeżeń wypada chyba zgodzić się z A. Etkindem, gdy pisze on, że

собственно ориенталистская, в традиционном смысле слова, классика большой русской прозы сравнительно небогата: „Путешествие в Арзрум”, „Хаджи-Мурат”, „Смерть Вазир-Мухтара”. К этому можно добавить десятки менее известных сочинений, но это не изменит очевидного вывода: отношения между Западом и Востоком имели существенно меньшее значение для русских классиков, чем отношения между государством и народом. В силу самореференциальности внутренней колонизации оппозиция государства и народа эффективно замещала оппозицию Запада и Востока. Представители государства и представители народа изображались литературой XIX века как люди принципиально разной природы - или, точнее, культуры. Столкновение двух персонажей, Человека из Народа и Носителя Власти и Культуры, было метанарративом многих классических текстов, которые драматизировали ситуацию внутренней колонизации, подняясь законам жанра ${ }^{36}$.

Jak zostało zauważone wcześniej, rosyjski literaturocentryzm poddawany jest od pewnego czasu rozbiórce. Ironiczne tematyzacje etosu pisarskiego (przypomnijmy casus Pielewina), coraz wyraźniej zaznaczająca się transgresja poststrukturalistycznego i kulturalistycznego sposobu myślenia, w połączeniu z generalnym spadkiem zainteresowania książką, skłaniają do rewizji przekonania o wyjątkowej, kulturotwórczej roli literatury. Nie unieważniają jednak jej żywotności w sferze głębszych uwarunkowań symboliczno-językowych. I czy interpretując zjawisko kolonialności/ imperialności kultury rosyjskiej od strony analizy tej właśnie sfery, nie natknęlibyśmy się przypadkiem na struktury kognitywne, gotowe - mówiąc żargonem formalistów - chwyty, na łatwiej czy trudniej rozpoznawalne metafory, postaci oraz symbole, które współczesna literatura wykorzystuje, w dodatku z dużym sukcesem, do poszerzania zakresu tejże kultury autonomiczności i wolności? Ergo - czy nie odkrylibyśmy w literaturze rosyjskiej wiarygodnego narzędzia emancypacji od dziedzictwa imperialnego? Wszak Moskwa-Pietuszki Wieniedikta Jerofiejewa, dzieło zapowiadające już u schyłku lat sześćdziesiątych XX wieku dojrzały rosyjski post-

36 А. Эткинд, Русская литература, ХІХ век: Роман внутренней колонизации, http://magazines.russ.ru/nlo/2003/59/etk.html (dostęp: 18.09.2018).

Miscellanea Posttotalitariana Wratislaviensia 8, 2020

(C) for this edition by CNS 
modernizm lat dziewięćdziesiątych, wykorzystuje złożony aparat intertekstualny do rozprawy z monolitycznością sowieckiej rzeczywistości. Intertekstualność ma tutaj, co znamienne, dwa dopełniające się wymiary: 1. jest płaszczyzną porozumienia z czytelnikiem, na której aktywizowane są kompetencje kulturowe tego ostatniego, niezbędne do podjęcia z nadawcą gry interpretacyjnej na przynajmniej minimalnym poziomie wspólnotowości; 2 . jest manifestacją pewnej wizji świata, eksponującą jego nieciągłość, niekoherencję oraz brak zakorzenienia w porządku logocentrycznym.

Stan kultury w ujęciu Wieniczki Jerofiejewa — zauważa Andrzej Dudek — to odzwierciedlenie dzisiejszego zagubienia człowieka, przytłoczonego chaosem szumów informacyjnych. W tych warunkach znajomość arcydzieł literatury i sztuki jest tylko pewną porcją nieuporządkowanej wiedzy, w żadnej mierze niezapewniającej formacji duchowej ${ }^{37}$.

Radykalna intertekstualizacja, godząca również w rodzimy literaturocentryzm, staje się jednocześnie, niejako mimowolnie, manifestacją godności zdezintegrowanego podmiotu: odczytujemy ją bowiem jako świadectwo wyrafinowania tegoż podmiotu, emanację jego głębokiej, egzystencjalnej i kulturowej, samoświadomości. Dla badacza postkolonialisty dzieło Jerofiejewa wykazuje się właściwościami trudnymi do przecenienia. Na jedną z nich wskażmy już teraz: autor Moskwy-Pietuszki pokazuje, w jakim obszarze realizuje się faktyczny demontaż rosyjskich struktur imperialnych.

W dojrzałym postmodernizmie rosyjskim znajdziemy znacznie więcej form przezwyciężania tradycyjnych struktur świadomościowych. Osobne miejsce zajmuje na tej niwie realistyczna proza Ludmiły Pietruszewskiej, pisarki znanej i cenionej również w Polsce. Właśnie w tak zwanej prozie kobiecej, reprezentowanej oprócz Pietruszewskiej również przez Walerię Nowodworską czy Tatianę Tołstoj, autorka Trubadurów imperium dostrzega symptomy dalej idących przewartościowań rosyjskiego modelu kultury określonego przez narodowe konstanty kulturowe. Pisarki te zdaniem Thompson

wydają się zdawać sobie sprawę, że imperialna tożsamość państwa rosyjskiego jest w trakcie przemian. [...] Wielkość przeszłości zastępują one nędzą teraźniejszości, podważają kolekcję obrazów imperialnych przez rekonstruowanie obrazów rosyjskiego niepowodzenia pośród imperialnego splendoru ${ }^{38}$.

Najściślejszy kanon poetyki postmodernistycznej określiła jednak, prawdopodobnie już na stałe, twórczość trzech pisarzy: przywołanego wcześniej Pielewina, Władimira Sorokina i Wiktora Jerofiejewa. Nie siląc się w ramach niniejszego szkicu na szukanie wspólnych mianowników między wymienionymi autorami, odnotujmy ich olbrzymi potencjał intertekstualny połączony z zasadniczą podejrzliwością wobec tradycyjnie (literaturocentrycznie właśnie) rozumianej wartości słowa. „Nie wie-

37 A. Dudek, „Droga Krzyżowa Wieniczki Jerofiejewa albo Rosja wódką umyta. O powieści Moskwa-Pietuszki”, [w:] Emigracja i tamizdat. Szkice o współczesnej prozie rosyjskiej, red. L. Suchanek, Kraków 1993, s. 259.

38 А. Эткинд, op. cit.

Miscellanea Posttotalitariana Wratislaviensia 8, 2020

(C) for this edition by CNS 
rzę w ani jedno rosyjskie słowo - powiada Wiktor Jerofiejew — ani oficjalne, ani drukowane, ani opozycyjne, ani niezależne, ani codzienne - każde słowo zawiera w sobie podstęp, zagrożenie, przemoc, niebezpieczeństwo dla życia" ${ }^{39}$. Z podejrzliwości i nieufności wyłania się wszelako imponujące dzieło eksploracji rozmaitych obszarów rosyjskiej i nie-rosyjskiej tekstualności: imperializmu, rewolucji bolszewickiej, kapitalizmu, rodzimej klasyki, srebrnego wieku, awangardy, wielkiej wojny ojczyźnianej, stalinizmu, orientalizmu, postmodernizmu, literaturocentryzmu itp. Rosyjski postmodernizm literacki przynosi zadziwiająco zniuansowaną odpowiedź na potrzebę - formułowaną przez nielicznych, lecz obiektywnie ważną - rewizji podstawowych założeń własnej kultury.

Inaczej jednak jest $\mathrm{z}$ rosyjskim dyskursem postkolonialnym oraz z podbudowującym go dyskursem historycznym i - do pewnego przynajmniej stopnia - politycznym. Interpelacja postkolonialna Zachodu skierowana do Rosji nie spotkała się dotąd z odpowiedzią, na jaką wielu liczyło. Rosyjska elita wciąż koduje doświadczenie imperialne własnego kraju oraz narodów ościennych w języku, który może być nie do przyjęcia dla kogoś, kto badaniom postkolonialnym przypisuje przede wszystkim cele etyczne - ów język zamazuje bowiem imperialną winę i pomniejsza kwestię moralnej za nią odpowiedzialności. Dlatego sensu angażowania aparatury postkolonialnej do badania fenomenu rosyjskiego imperializmu/kolonializmu upatruję w czymś innym niż - jak to miało miejsce dotychczas - w próbie zaadaptowania go do dyskursywnych matryc wypracowanych przez główny (zachodni) nurt postcolonial studies, a także — od pewnego czasu — środkowo-wschodnioeuropejskich. Myślę, że badania te powinny podążać szlakiem wytyczanym nie przez rosyjski dyskurs postkolonialny, lecz przez rosyjski postmodernizm.

Ten pierwszy wypada bowiem uważać raczej za uczestnika debaty tożsamościowej w Rosji (i częściowo poza nią w przypadku rosyjskich intelektualistów funkcjonujących w przestrzeni międzynarodowej, jak na przykład M. Tłostanowa), ze wszystkimi wynikającymi z tego faktu konsekwencjami natury kulturowej. Jedną $\mathrm{z}$ takich konsekwencji jest, moim zdaniem, tendencja do reprodukowania postaw i idei zakorzenionych w rosyjskich konstantach kulturowych. Koronnym przykładem występowania rzeczonej tendencji może być akcentowanie kwestii rosyjskich cierpień kosztem rosyjskich win. Wiąże się to z koncentrowaniem uwagi na „kolonizacji wewnętrznej”, przedstawianej w pierwszej kolejności jako źródło ucisku ludu rosyjskiego (czytaj: wielkoruskiego) oraz na nie mniej idiosynkratycznie rozumianej „kolonizacji zewnętrznej”, w ramach której to Rosja, a nie kraje od niej uzależnione lub przez nią podbite, uzyskuje status pierwszoplanowej ofiary (Zachodu, systemu międzynarodowego, procesów globalizacyjnych itp.). Oczywiście dojrzałe studium postkolonialne nie powinno bagatelizować tych aspektów kolonialnego/imperialnego doświadczenia, które eksponuje dyskurs rosyjski. Notoryczne przypisywanie mu intencji fałszowania historii czy manipulowania faktami - z czym można spo-

39 A. Dudek, op. cit., s. 259. 
tkać się niekiedy w polskim dyskursie publicznym — wypada uznać za rodzaj szkodliwej i nieuprawnionej demonizacji rosyjskiej (auto)percepcji kulturowej. Rosyjskie prawo do artykulacji własnej wrażliwości postkolonialnej winno być honorowane w stopniu analogicznym do praw nierosyjskich podmiotów debaty.

Rosyjski postmodernizm natomiast, mimo swojej wielostylowości (współwystępowanie różnych konwencji: realistycznej, konceptualizmu, metarealizmu, parodii, groteski itp.) i wielopodmiotowości (pojawienie się kilku-kilkunastu wybitnych indywidualności twórczych kształtujących zewnętrzny obraz kierunku), da się postrzegać jako zespół praktyk i postaw wyraźnie mniej obciążonych ideologicznie niż dyskurs postkolonialny. Nadto wypracował on w ciągu kilku już dziesięcioleci swojego istnienia atrakcyjny dla odbiorców model przekodowywania rosyjskich konstant na kategorie kultury popularnej, a także nie mniej atrakcyjny język ich narratywizacji. Konstantą transformowaną na potrzeby nowego, emancypującego się od tradycyjnych źródeł samoidentyfikacji odbiorcy (dotyczy to wszelako również, a nawet przede wszystkim, twórców) jest niewątpliwie literaturocentryzm. Obniżenie społecznej rangi literatury ma oczywiście swój wymiar psychologiczny i wymaga ze strony autorów pewnych działań kompensujących utratę wcześniejszego statusu. Ale nie zmienia to faktu, że dzięki osadzeniu w tradycji literaturocentrycznej rosyjski pisarz-postmodernista, niezależnie od osiągniętego poziomu autotelizacji swoich praktyk twórczych, a także niezależnie od wielkości pola społecznej autonomii, do której rości sobie prawo, wchodzi w interakcję z rodzimym dyskursem tożsamościowym. Tradycja literaturocentryczna prefiguruje wypowiedź literacką jako akt komunikacyjny, którego doniosłość wykracza poza jego funkcje estetyczne.

Ta sama literatura, która wykazywała niegdyś zdolność do współkreowania imperialnego splendoru państwa carów, okazała się - tym razem w szacie nowoczesnej ironistki - nie mniej skuteczną kreatorką nowego języka literatury i odnowionej formy pisarskiej podmiotowości. Utwierdzony przez kilkupokoleniową tradycję literaturocentryzm, będący residuum nośnych społecznie metafor i wartości, wciąż może być traktowany jako forma kapitału społecznego, legitymizująca literaturę w jej aspiracjach do bycia wyróżnionym społecznie forum wypowiedzi. Forum, na którym dokonuje się praca myśli daleko bardziej brzemienna w intelektualne i moralne konsekwencje, niż ma to miejsce w wypadku innych rosyjskich dyskursów.

Spośród dwóch komponentów fundujących właściwość badań postkolonialnych, krytyki społecznej o marksizującym obliczu (Frantz Fanon, Edward Said ${ }^{40}$ ) oraz poststrukturalizmu niewątpliwie ten drugi wypada uznać za bardziej obiecujący kierunek dla badań nad Rosją w kontekście postkolonialnym. Poststrukturalistyczne motywacje literatury rosyjskiego postmodernizmu są w Rosji, jak na razie, najbardziej „realnym” źródłem inspiracji do przewartościowań na gruncie własnych rozrachunków z imperialną przeszłością.

${ }^{40}$ E. Thompson, op. cit., s. 312. 


\section{Bibliografia}

Bakuła, Bogusław. 2014. „Rosyjska wewnętrzna kolonizacja”, Porównania 15: 341-356.

Берг, Михаил. 2000. Литературократия. Проблема присвоения и перераспределения власти в литературе. Москва: Новое литературное обозрение.

Берг, Михаил. 2004. Постколониальный дискурс и проблема успеха в современной русской литеpamype, http://mberg.net/pstk/ (dostęp: 17.09.2018).

Берг, Михаил. 2007. „О статусе литературы”, Дружба Народов 7, http://magazines.russ.ru/druzhba/ 2000/7/berg.html (dostęp: 16.09.2018).

Brodziński, Kazimierz. 1995. „Myśli o dążeniu polskiej literatury. Fragmenty”. W: Oświeceni o literaturze, t. 2. Wypowiedzi pisarzy polskich 1801-1830, oprac. Teresa Kostkiewiczowa, Zbigniew Goliński. Warszawa: PWN. 221-239.

Czechowski, Wiesław. 2004. „Zakłócenia w językowej komunikacji jako problem badawczy”, Linguistica Bidgosiana, https://repozytorium.ukw.edu.pl/ (dostęp: 21.09.2018).

Добренко, Евгений. 1997. Формовка советского читателя. Социальные и эстетические предпосылки рецепции советской литературы. Санкт-Петербург: Академический проект.

Dudek, Antoni. 1993. „Droga Krzyżowa Wieniczki Jerofiejewa albo Rosja wódką umyta. O powieści Moskwa-Pietuszki". W: Emigracja i tamizdat. Szkice o współczesnej prozie rosyjskiej, red. Lucjan Suchanek. Kraków: Universitas.

Эпштейн, Михаил. 2000. Постмодерн в России. Литература и теория. Москва: Издание Р. Элинина.

Эпштейн, Михаил. 2005. Постмодерн в русской литературе, Москва: Высшая школа.

Эткинд, Александр. 2001. Фуко и тезис внутренней колонизации: постколониальный взгляд на советское прошлое, http://magazines.russ.ru/nlo/2001/49/etkind-pr.html (dostęp: 25.09.2018).

Эткинд, Александр. 2003. Русская литература, ХІХ век: Роман внутренней колонизации, http:// magazines.russ.ru/nlo/2003/59/etk.html (dostęp: 18.09.2018).

Etkind, Aleksander. 2011. Internal colonisation. Russia's imperial experience. Cambridge: Polity Press.

Galster, Bohdan. 1970. „Idealiści moskiewscy”. W: Literatura rosyjska, t. 1, red. Marian Jakóbiec, 601-611. Warszawa: PWN.

Евтушенко, Евгений. 2007. Поэт в России — больще, чем поэт, https://www.stihi.ru/2007/11/17/1193 (dostęp: 20.09.2018).

Jerofiejew, Wiktor. 2004. Encyklopedia duszy rosyjskiej. Romans z encyklopedia. Przeł. Andrzej de Lazari. Warszawa: Czytelnik.

Kołodziejczyk, Dorota. 2010. „Postkolonialny transfer na Europę Środkowo-Wschodnią”, Teksty Drugie. Teoria literatury, krytyka, interpretacja 5: 22-39.

Корнев, Сергей. 1997. „Столкновение пустот: может ли постмодернизм быть русским и классическим?", Новое титературное обозрение 28: 244-259.

Lazari, Andrzej de, red. 1995. Słownik mentalności rosyjskiej. Katowice: Śląsk Sp. z o.o.

Любавский, Матвей К. 1996. Обзор истории Русской колонизации с древнейших времен и до XX века. Москва: Издательство Московского университета.

Madajczyk, Czesław. 1999. Klerk czy intelektualista zaangażowany?, Poznań: Wydawnictwo Poznańskie.

Morozov, Viatcheslav. 2015. Russia's postcolonial identity. A subaltern empire in a eurocentric world. Basingstoke: Palgrave Macmillan.

Немзер, Андрей. 2000. „Замечательное десятилетие. О русской прозе 90-х годов”, Новый Мир 1: 206-219.

Pipes, Richard. 2006. Rosja carów, przeł. W. Jeżewski. Warszawa: Magnum.

Постановление Политбюро ЦК РКП(б) О политике партии в области художетвенной литераmypы (18 июня 1925 г.), http://www.hist.msu.ru/ER/Etext/USSR/1925.htm (dostęp: 23.09.2018).

Пушкин, Александр С. 2010. Эхо русского народа, https://www.stihi.ru/2010/01/10/8357 (dostęp: 20.09.2018).

Miscellanea Posttotalitariana Wratislaviensia 8, 2020

(C) for this edition by CNS 
Spivak, Gayatri C. 2011. Strategie postkolonialne. Przeł. Antoni Górny, Maciej Kropiwnicki. Warszawa: Wydawnictwo Krytyki Politycznej.

Thompson, Ewa M. 2000. Trubadurzy imperium. Literatura rosyjska i kolonializm. Przeł. Anna Sierszulska. Kraków: Universitas.

Tlostanova, Madina. Towards a decolonization of thinking and knowledge: a few reflections from the world of imperial difference, https://antville.org/static/sites/m1/files/madina_tlostanova_decolonia_thinking.pdf (dostęp: 29.08.2018).

Tłostanowa, Madina. 2015. „Postsowieckość ₹ poskolonialność $\neq$ postimperialność, czyli co robić po końcu historii?", przeł. Piotr Fast, ER(R)GO. Teoria-Literatura-Kultura 2 (31): 145-155, http://bazhum.muzhp.pl/media//files/ER(R)GO_Teoria_Literatura_Kultura/ER(R)GO_Teoria_Literatura_ Kultura-r2015-t-n2_(31)/ER(R)GO_Teoria_Literatura_Kultura-r2015-t-n2_(31)-s145-155/ER(R) GO_Teoria_Literatura_Kultura-r2015-t-n2_(31)-s145-155.pdf (dostęp: 29.08.2018).

Вдали от комплексных идей живешь, как Рэмбо - day by day, Liza Nowikowa w wywiadzie z Wiktorem Pielewinem. http://pelevin.nov.ru/interview/o-komrs/1.html (dostęp: 20.09.2018).

Woźniak, Anna. 2016. „O literaturze rosyjskiej, jej nauczaniu i literaturocentryzmie”, Roczniki Humanistyczne 64, z. 7: 43-62.

Przyjęto do druku/Accepted for publication: 30.09.2019

Miscellanea Posttotalitariana Wratislaviensia 8, 2020

(C) for this edition by CNS 